\title{
Properties of boundary-line release criteria in North American tree species
}

\author{
Bryan A. BlACK ${ }^{1 *}$, Marc D. ABRAMS ${ }^{2}$, James S. RENTCH ${ }^{3}$, Peter J. GoulD \\ ${ }^{1}$ Hatfield Marine Science Center, 2030 Marine Science Drive, Newport, OR 97365, USA \\ 24 Ferguson Building, School of Forest Resources, Penn State University, University Park, PA 16802, USA \\ ${ }^{3}$ Division of Forestry and Natural Resources, West Virginia University, P.O. Box 6125, Morgantown, WV 26506, USA \\ ${ }^{4}$ US Forest Service, Forest Sciences Laboratory, $362593^{\text {rd }}$ Ave. SW, Olympia, WA 98512, USA
}

(Received 18 June 2008; accepted 26 November 2008)

Keywords: dendrochronology / disturbance ecology / forest ecology / release criteria

Mots-clés :

dendrochronologie /

écologie des perturbations /

écologie forestière /

critères de dégagement

\begin{abstract}
- Boundary line release criteria are increasingly applied to evaluate forest disturbance histories from tree-ring data. However, a number of important properties central to the technique have not been evaluated, including: (i) the ability of boundary line release criteria to standardize releases across various sites, species, and tree life stages (ii) the minimum sample sizes necessary for developing boundary lines, and (iii) the degree to which the criteria can resolve the degree of crown exposure following a disturbance event.

- In an analysis of eleven North American tree species, boundary line release criteria do not fully compensate for declines in release response a tree experiences with increasing age and size, with the exception Tsuga canadensis.

- A bootstrapping analysis indicates that approximately 50000 ring width measurements are necessary to develop boundary line release criteria for a given species.

- In a Quercus prinus stand, boundary line release criteria better predict the degree of crown exposure following a disturbance than an earlier running mean technique.

- Despite certain limitations, boundary line release criteria have the potential to standardize release calculation across most life stages of a tree, and possibly among sites and species.
\end{abstract}

Résumé - Propriétés des critères des lignes limites de dégagement chez les arbres Nord Américains.

- Les lignes limites de dégagement sont des critères de plus en plus appliqués pour évaluer l'historique des perturbation des forêts à partir des données des cernes des arbres. Toutefois, un certain nombre de propriétés importantes au cœur de la technique n'ont pas été évaluées, y compris : (i) la capacité du critère de la ligne limite de dégagement pour standardiser les dégagements à travers différents sites, espèces et stades de la vie des arbres, (ii) la taille minimale des échantillons nécessaires pour le développement de lignes limites, et (iii) le degré avec lequel les critères peuvent résoudre le degré d'exposition de la couronne suite à un événement perturbant.

- Dans une analyse de onze espèces d'arbres d'Amérique du Nord, les critères de ligne limite ne compensent pas entièrement la baisse de réponse au dégagement d'un arbre en relation avec l'âge et la dimension, à l'exception Tsuga canadensis.

- Une analyse bootstrap indique que près de 50000 mesures de largeur sont nécessaires pour développer des critères de ligne limite de dégagement pour une espèce donnée.

- Dans un peuplement de Quercus prinus, les critères de ligne limite de dégagement permettent de mieux prédire le degré d'exposition de la couronne à la suite d'une perturbation que la technique de la moyenne courante.

- En dépit de certaines limitations, les critères de ligne de limite de dégagement ont le potentiel de standardiser les calculs de dégagement dans la plupart des étapes de la vie d'un arbre et, éventuellement, entre les sites et les espèces.

\footnotetext{
*Corresponding author: bryan.black@ oregonstate.edu
} 


\section{INTRODUCTION}

Tree rings represent a key data source for reconstructing forest dynamics and disturbances such as windstorms, ice storms, fires, insect outbreaks, logging, and agricultural activities (Abrams et al., 2001; Lafon and Speer, 2002; Lorimer and Frelichn, 1989; Shumway et al., 2001; Speer et al., 2001). The timing, duration, and magnitude of these events are often inferred by analyzing the growth pulses, also known as releases, associated with disturbance-related reductions in competition. Over the past several decades a wide range of criteria for identifying releases have been developed to quantify disturbance histories using time series of tree-ring measurements (Rubino and McCarthy, 2004). Some of the most widely used are radial-growth averaging techniques, in which a running percent-growth change calculation is performed on each treering time series, and release events are indicated when percentgrowth change values exceed a certain minimum value. For example, in the Nowacki and Abrams (1997) criteria, percentgrowth change is calculated in 10-year running windows with a release threshold of twenty-five percent. These criteria have been successfully applied in a number of studies (Rozas, 2003; Schuler and Fajvan, 1999; Winter et al., 2002), validated by independent testing (Rentch et al., 2002), and found to reflect the magnitude and timing of percent crown exposure (Rentch et al., 2003).

The Nowacki and Abrams (1997) criteria were originally designed to address crown releases in dominant and codominant trees, but may not be appropriate to apply to younger, smaller individuals. In comparison to overstory trees, which are already growing near an optimum level, suppressed understory trees often show much more dramatic growth responses in response to reduced competition (Black and Abrams, 2004; Lorimer and Frelich, 1989). To compensate for these differences in release response, some have employed a hybrid approach in which more stringent criteria are applied to the understory phase of growth (Ruffner and Abrams, 1998). Building on this concept, boundary line release criteria were proposed to better account for differences in release response throughout the lifespan of the tree. The technique was based on the observation that prior radial growth rate was a strong predictor of the maximum percent-growth change pulse the tree could experienced following a disturbance event (Black and Abrams, 2003). In summary, young, small, and suppressed trees maintained slower radial growth rates, and were found to be capable of extremely large pulses in percent-growth change in comparison to their older, larger, dominant counterparts. Radial growth rate appeared to be closely related to the magnitude of percent-growth change pulses. Indeed, when percentgrowth change was graphed against average radial growth over the past ten years, percent growth-change values extended to a well-defined boundary that declined exponentially across increasing levels of prior growth (Black and Abrams, 2003).

An important aspect of this finding is that Tsuga canadensis of almost any age, size, and canopy class demonstrated percent growth-change pulses that reached this upper boundary, with the exception of sites near the boundaries of the species' range (Black and Abrams, 2004). Slow-growing trees, which tended to be small understory individuals, reached the boundary with large pulses in percent-growth change. Fast-growing trees, which tended to be large dominant individuals, could reach the boundary with only modest pulses in percent-growth change. Release criteria were proposed in which all percent growth-change pulses are scaled in terms of their maximum possible value, as predicted by level of prior radial growth. This should better compensate for differences among age, size, and canopy classes and allow for better direct comparisons of release events across all phases of a tree's lifespan.

In addition to Tsuga canadensis, strong effect of prior growth has been demonstrated for the North American tree species Pinus strobus, Pinus echinata, Quercus macrocarpa, Quercus alba, Quercus prinus, Pseudotsuga menziesii (Black and Abrams, 2003; 2004), Ilex opaca (Forrester et al., 2007), and Betula alleghaniensis (Webster and Jensen, 2007), as well as the European tree species Fagus sylvatica, Abies alba, and Picea abies (Nagel et al., 2007; Splechtna et al., 2005). As in Tsuga canadensis, the upper thresholds of percentgrowth change follow negative exponential trends with increasing levels of prior growth. However, the configuration of each species' boundary line is unique, reflecting differences in life history characteristics and thus, release response (Black and Abrams, 2003; 2004; Splechtna et al., 2005). By scaling each percent-growth change pulse to the maximum value predicted by prior growth, boundary line release criteria may also help compensate for species-specific differences in release response, facilitating more direct comparisons of disturbance histories among species and sites (Black and Abrams, 2003; 2004).

In this study we address a number of issues related to boundary line development and the assumptions underlying the criteria using eleven North American tree species that occur in diverse habitats and have contrasting ecological characteristics: Tsuga canadensis, Pinus strobus, Pinus echinata, Pinus ponderosa, Quercus macrocarpa, Quercus alba, Quercus prinus, Quercus stellata, Picea glauca, Picea mariana, Pseudotsuga menziesii. Specifically, the objectives are to (i) develop boundary lines for Pinus ponderosa, Quercus stellata, Picea glauca, and Picea mariana, and compare them to all other boundary lines that have been created to date, (ii) apply a bootstrapping analysis to estimate the minimum sample size necessary to develop a boundary line, (iii) identify whether the boundary line release criteria fully compensates for ageand size-related changes in release response, and (iv) assess the extent over which a single boundary line may be applied. Finally, we evaluate the ability of boundary-line release criteria to resolve the degree of crown release in a Quercus prinus stand with a known disturbance history. Overall, we more thoroughly evaluate the strengths and weaknesses of boundary line release criteria and discuss interpretations of release events detected through this technique.

\section{MATERIALS AND METHODS}

\subsection{Boundary line development and effects of age and size}

Tree-ring data were obtained from previous studies and the International Tree-Ring Data Bank (Appendix available online at www. 
afs-journal.org). Percent-growth change and prior growth were calculated for all tree ring data following the formula of Nowacki and Abrams (1997) in which percent-growth change for a year equals $\left(\mathbf{M}_{2}\right.$ $\left.-M_{1}\right) / M_{1}$ where $M_{1}$ equals average growth over the prior 10 years and $\mathrm{M}_{2}$ equals average growth over the subsequent 10 years. Prior growth was defined as the average radial growth over the past ten years (Black and Abrams, 2004). For each species, the boundary line was constructed by first dividing the data set into $0.5 \mathrm{~mm}$ segments of prior growth. Then within each segment, the percent-growth change values of the top ten points were averaged. The top ten points in each section ensured an equal sample size across all prior growth classes, and limited the analysis to the few points that represented true maximal releases. To quantify the boundary line linear, power, logarithmic, and exponential curves were fitted to all positive segment averages, and the function that yielded the highest $R^{2}$ value was selected (Black and Abrams, 2003; 2004).

Approximate age of each growth increment was estimated by counting all preceding growth rings, while radius was estimated by summing the widths of all preceding growth rings. Growth increments were assigned radius classes in $50 \mathrm{~mm}$ increments $(0$ $49.9 \mathrm{~mm}, 50-99.9 \mathrm{~mm}$, etc.) and age classes in 50 year increments (0-49 years, 50-99 years, etc.). All growth increments were plotted with respect to age or radius class, prior growth, and percent-growth change to evaluate difference in percent growth changes among age and radius classes. If all age and radius classes approach the upper threshold of percent-growth change values, then all classes are capable of maximum percent-growth change as predicted by prior growth. If any age and radius classes fell short of the threshold, then the effects of prior growth on maximum percent-growth change did not adequately explain percent growth change differences among age or radius classes.

\subsection{Minimum sample sizes}

A bootstrapping test to estimate minimum sample size was conducted by sampling percent-growth change values with replacement at increasingly large sample sizes. Sampling from each species' complete data set began at 10000 growth increments and increased in steps of 10000 to a maximum of 200000 percent-growth change values. The prior growth rate associated with each percent-growth change value was retained. For each species, sampling was replicated 300 times at each of the twenty sample sizes to yield a total of 6000 resamplings. In every sampling replicate, data were divided into $0.5 \mathrm{~mm}$ prior growth classes $(0.0-0.49 \mathrm{~mm}, 0.5-0.99 \mathrm{~mm}$, etc.) and the top ten percent-growth change values in each class were averaged. The mean, standard deviation, and coefficient of variation of these 300 percent-growth change averages were calculated in each prior growth class. Minimum sample size was estimated by plotting standard deviation and mean across all sample sizes (10000 to 200 000) and identifying the sample size at which both become asymptotic. The coefficient of variation (standard deviation/mean) was calculated in order to summarize the combined effects of increasing mean and decreasing standard deviation that typically occur with increasing sample size.

\subsection{Boundary-line release criteria validation}

The ability of boundary-line release criteria to resolve crown exposure was evaluated using Quercus prinus increment cores from thinned stands in West Virginia (Rentch et al., 2002). The study site is located on a northeast-facing upper slope of Chestnut Ridge in the West Virginia University Forest, $13 \mathrm{~km}$ east of Morgantown WV. Elevation is $640 \mathrm{~m}$ and slopes range from 0 to $15 \%$ and soils are derived from resistant sandstone and are acidic with low fertility (Rentch et al., 2002). Twenty oak-dominated 1.2-ha experimental plots were thinned in 1982 at one of three treatment levels: 45, 60, or $75 \%$ relative density. Four years later, dominant and codominant trees were assigned a free-to-grow rating from 0 (control; no crown release) to 4 (crown fully released) in increments of 0.5 (Rentch et al., 2002). In 2000, dominant and codominant Quercus prinus $(n=52)$ were randomly selected in each of the crown release classes $(0,12.5$, $25,37.5,50,67.5,75,87.5$, and $100 \%$ ) for coring. These cores were mounted, sanded, cross-dated, and measured according to standard dendrochronological techniques.

Prior growth and percent-growth change were calculated for every growth increment within every tree-ring series, with the exception of the first and last ten years of growth, in which these calculations could not be applied. In the percent-growth change pulses that followed the 1982 thinning, the year of maximum percent-growth change was identified and the percent-growth change value and prior growth level were recorded. If no discernable pulse occurred following the thinning, as was the case in the controls and some $12.5 \%$ crown releases, percent-growth change and prior growth were recorded for 1985 . This compensates for the average three-year lag that occurred before the maximum value of percent-growth change (Rentch et al., 2002). For each tree, maximum percent-growth change and prior growth following the thinning were plotted with respect to the specieswide Quercus prinus boundary line, described by the function: $y=742.83 \mathrm{e}^{-0.9977 x}$ (Black and Abrams, 2003).

\section{RESULTS AND DISCUSSION}

\subsection{Boundary line properties}

Prior growth strongly influences maximum percent-growth change in all of the very diverse species reviewed by this study. The relationship between prior growth and percent growth change consistently follows a declining trend such that trees experiencing slow growth are capable of much larger pulses in percent growth change than those experiencing rapid growth (Tab. I and Fig. 1). However, boundary line configuration varies considerably among species, in such a way that loosely followed each species' level of understory tolerance (Fig. 1). For example, in the shade-tolerant Fagus sylvatica, Abies alba, Ilex opaca, and Tsuga canadensis, maximum percent-growth change values are quite high when prior growth is slow, and then steeply decline as prior growth rate increases (Fig. 1A). In contrast, maximum percent-growth change of the intermediate and shade-intolerant species is much lower when prior growth is slow, as is the rate of decline in these values as prior growth increases (Figs. 1B and 1C). Such a pattern in the boundary lines makes ecological sense considering that these species are capable of sustaining extremely low growth rates and rapidly exploiting any newly formed gaps (Black and Abrams, 2003). However, there are several notable exceptions to this pattern, such as the very low percent growth change values for the shade-tolerant Picea mariana (Fig. 1A), or the rather high boundary line values for Betula alleghaniensis and 
Table I. Tolerance rankings and boundary line equations, sample sizes, and understrory tolerance ratings for eleven North American tree species included in this study or Black and Abrams 2003 or 2004. The percentage of sites in which trees approach the boundary line is shown, as is the age and size at which each species fails to attain maximum release responses predicted by the prior-growth boundary line, also expressed as a percentage of the maximum size ( $\%$ of max size) and maximum age ( $\%$ of max age) observed for each species.

\begin{tabular}{|c|c|c|c|c|c|c|c|c|c|}
\hline Species & $\begin{array}{c}\text { Boundary line } \\
\text { equation }\end{array}$ & $\begin{array}{c}N \\
\text { sites }\end{array}$ & $\begin{array}{l}N \text { growth } \\
\text { increments }\end{array}$ & $\begin{array}{c}\text { Shade-tolerance } \\
\text { rating }\end{array}$ & $\begin{array}{c}\text { Radius } \\
(\mathrm{mm})\end{array}$ & $\begin{array}{c}\text { Age } \\
\text { (years) }\end{array}$ & $\begin{array}{l}\% \text { of } \\
\text { sites }\end{array}$ & $\begin{array}{c}\% \text { of } \max \\
\text { size }\end{array}$ & $\begin{array}{c}\% \text { of } \max \\
\text { age }\end{array}$ \\
\hline Tsuga canadensis & $y=974.54 \mathrm{e}^{-1.1202 x}$ & 25 & 180,708 & Tolerant & 350 & 350 & 30 & 78 & 64 \\
\hline Picea mariana & $y=407.92 \mathrm{e}^{-1.4679 x}$ & 26 & 49,007 & Tolerant & 200 & 250 & 19 & 80 & 63 \\
\hline Average & & & & & & & 22 & 80 & 54 \\
\hline Pseudotsuga menziesii & $y=569.80 \mathrm{e}^{-0.928 x}$ & 25 & 172,372 & Intermediate & 300 & 300 & 36 & 60 & 33 \\
\hline Quercus prinus & $y=742.83 \mathrm{e}^{-0.9445 x}$ & 8 & 35,337 & Intermediate & 200 & 200 & 29 & 50 & 50 \\
\hline Pinus strobus & $y=501.96 \mathrm{e}^{-0.664 x}$ & 12 & 72,714 & Intermediate & 200 & 250 & 47 & 44 & 63 \\
\hline Average & & & & & & & 38 & 45 & 48 \\
\hline Quercus stellata & $y=948.45 \mathrm{e}^{-1.6188 x}$ & 23 & 169,333 & Intolerant & 150 & 50 & 39 & 50 & 13 \\
\hline Quercus macrocarpa & $y=511.27 \mathrm{e}^{-0.7018 x}$ & 38 & 92,092 & Intolerant & 100 & 100 & 34 & 29 & 29 \\
\hline
\end{tabular}

Pinus echinata (Figs. 1B and 1C). Thus, the steepest boundary lines generally tend to occur in shade-tolerant species, but this generalization is not always true.

For most species, simple negative exponential functions provide a good fit. Yet for some species, modifications were necessary to follow steeply declining values of percent growth change (Splechtna et al., 2005). In Fagus sylvatica, Picea abies, and Abies alba, parameters were added so the functions would better fit the relationship between prior growth and percent growth change. Also, for Fagus sylvatica, data were subdivided into $0.25 \mathrm{~mm}$ classes to capture the very rapid declines observed in percent growth change values (Splechtna et al., 2005). On a more fundamental level, the procedure of quantifying an upper boundary remains somewhat subjective, and other alternatives could be explored. The number of maximal data points in each prior growth class could be varied, as could the width of each prior growth class, or the functions used to fit the relationship between prior growth and percentgrowth change. An approach such as quantile regression could be considered, which would identify the upper boundary using all points in the data set rather than the highest percent growth change values in each prior growth class (Cade and Noon, 2003). Such techniques could potentially improve the criteria, though major alterations of boundary lines would require the redefinition of thresholds for "moderate" or "major" releases as well as the lowest thresholds necessary to exclude the effects of climate.

\subsection{Adequate sample sizes for boundary line development}

Another important aspect of boundary line release criteria is identifying the minimum sample size of growth increments necessary for boundary line development. According to bootstrapping analysis for Tsuga canadensis, the mean percent growth change in each prior growth class increases with increasing sample size, and the increase is most rapid in the smallest $(0.25 \mathrm{~mm})$ prior growth class (Fig. 2A). Also, standard deviation in the smallest prior growth class decreases until a sample size of approximately 150000 after which point it remains stable through a sample size of 200000 growth increments (Fig. 2B). The combined effects of increasing mean and decreasing standard deviation are reflected in the coefficient of variation, which declines in all prior-growth classes as sample size increases. In comparison to the slowest prior growth classes $(0.25$ and $0.75 \mathrm{~mm})$, the coefficients of variation in the highest growth classes $(2.25$ and $2.75 \mathrm{~mm}$ ) appear to be quite large. However, this is due to low values of the mean, which are subject to yield high coefficients of variation even when accompanied by low standard deviation values (Fig. 2).

The most relevant property of the coefficient of variation is its pattern of change with increasing sample size, which follows similar patterns across all prior growth classes. In almost every prior growth class, the steepest declines in the coefficient of variation occur between sample sizes of approximately 10000 to 50000 , thereafter only gradually declining with increasing sample size (Fig. 2C). Where the coefficient of variation stabilizes indicates the point at which the mean is at its maximum and the variance around that mean is stable. In Tsuga canadensis, that point is reached at a sample size of approximately 50000 data points. Beneath this sample size the maximum possible percent-growth change values could be underestimated, particularly in the highest $(2.75 \mathrm{~mm})$ prior growth class.

Coefficients of variation are shown for six other species, representative of the eleven total species in the sample set 


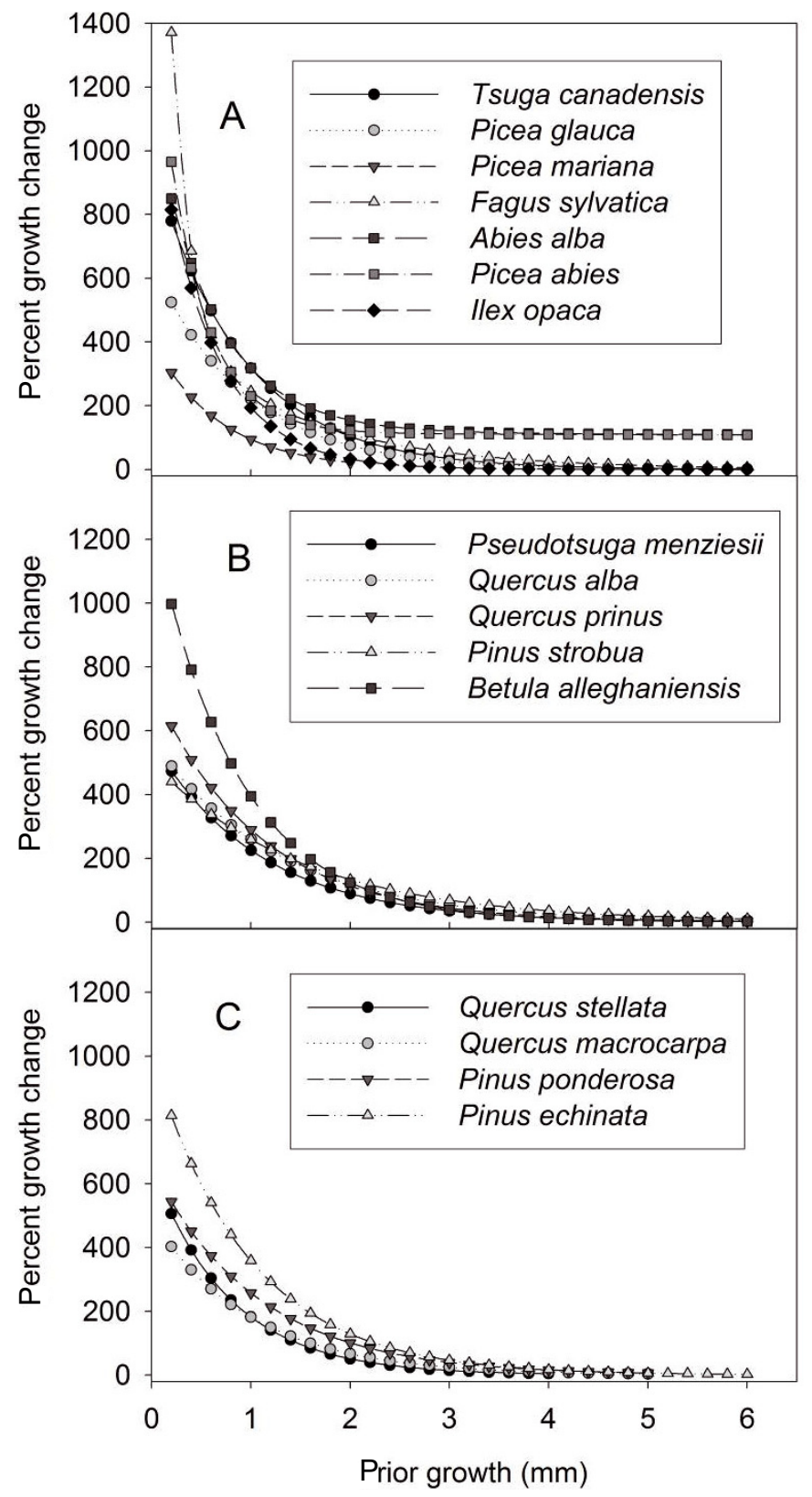

Figure 1. Boundary lines for (A) shade-tolerant species, (B) species of intermediate tolerance, and (C) shade-intolerant species.

(Fig. 3). In general, the patterns are similar to Tsuga canadensis whereby the fastest prior growth classes are subject to highest coefficients of variation, especially for sample sizes less than 50000 (Figs. 3 and 2C). Once the sample size reaches 50000 , the decline in the coefficient of variation generally stabilizes and approaches a value of ten percent. The only exception is Tsuga canadensis, in which the coefficient of variation stabilizes at values closer to fifteen percent (Fig. 2C). Considering that is the pair where the coefficient of variation begins to stabilize, 50000 should be a sufficient sample size for boundary line development in most species. However, particu-

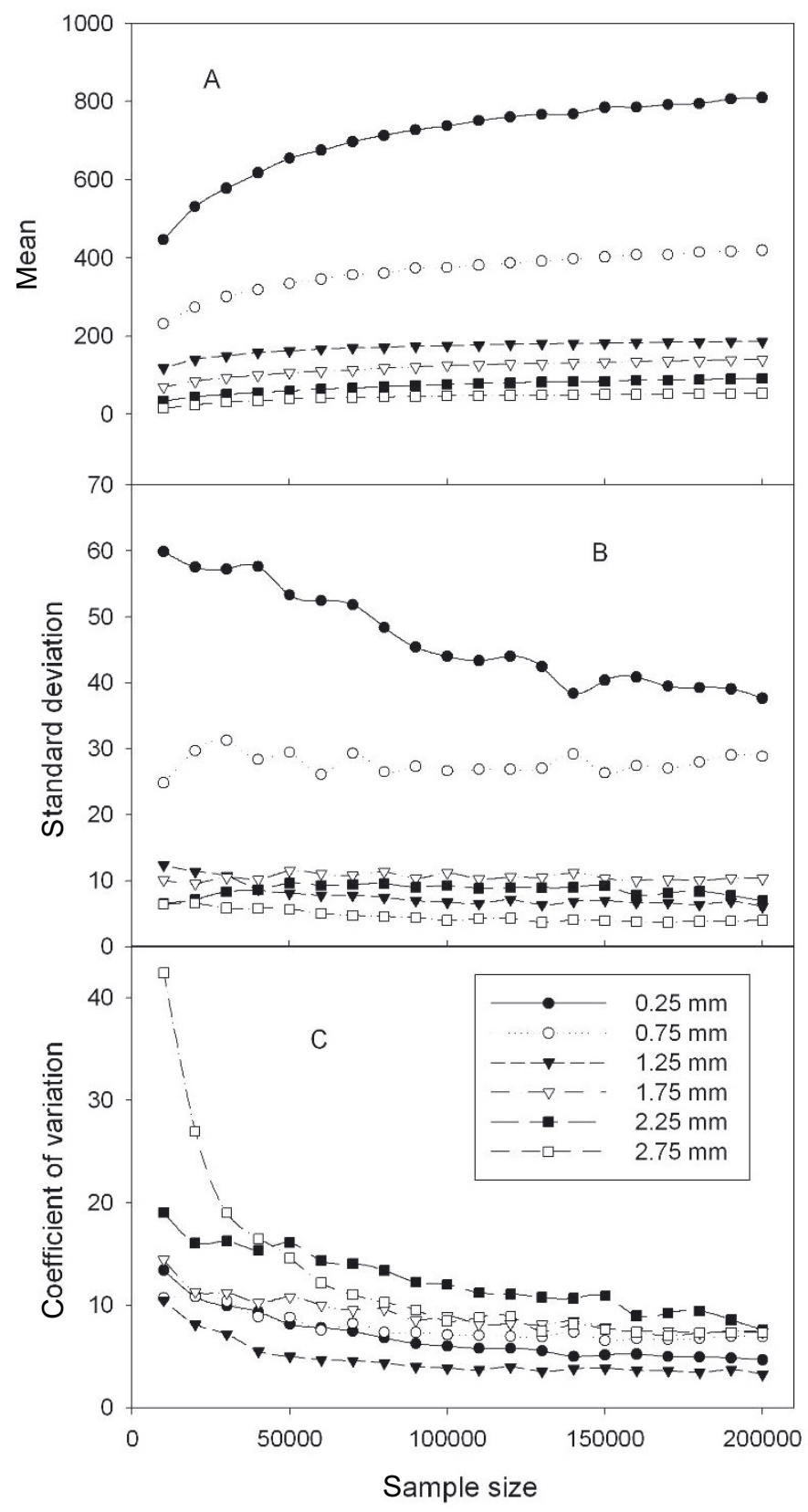

Figure 2. (A) Means, (B) standard deviations, and (C) the coefficients of variation of maximum percent-growth change in $0.5 \mathrm{~mm}$ prior-growth classes for Tsuga canadensis. Three hundred resamplings were performed at each sample size.

lar caution should be given to the highest prior growth classes, which are subject to the largest coefficient of variation values.

Definitive conclusions about the necessary sample sizes of each species are not possible to discern from this bootstrapping test, and the minimum sample size of 50000 should only be considered as a rough guideline, especially for the highest prior growth values. The tree-ring collections represented in this study are far from random and may contain a number of biases. This is especially true for collections in 

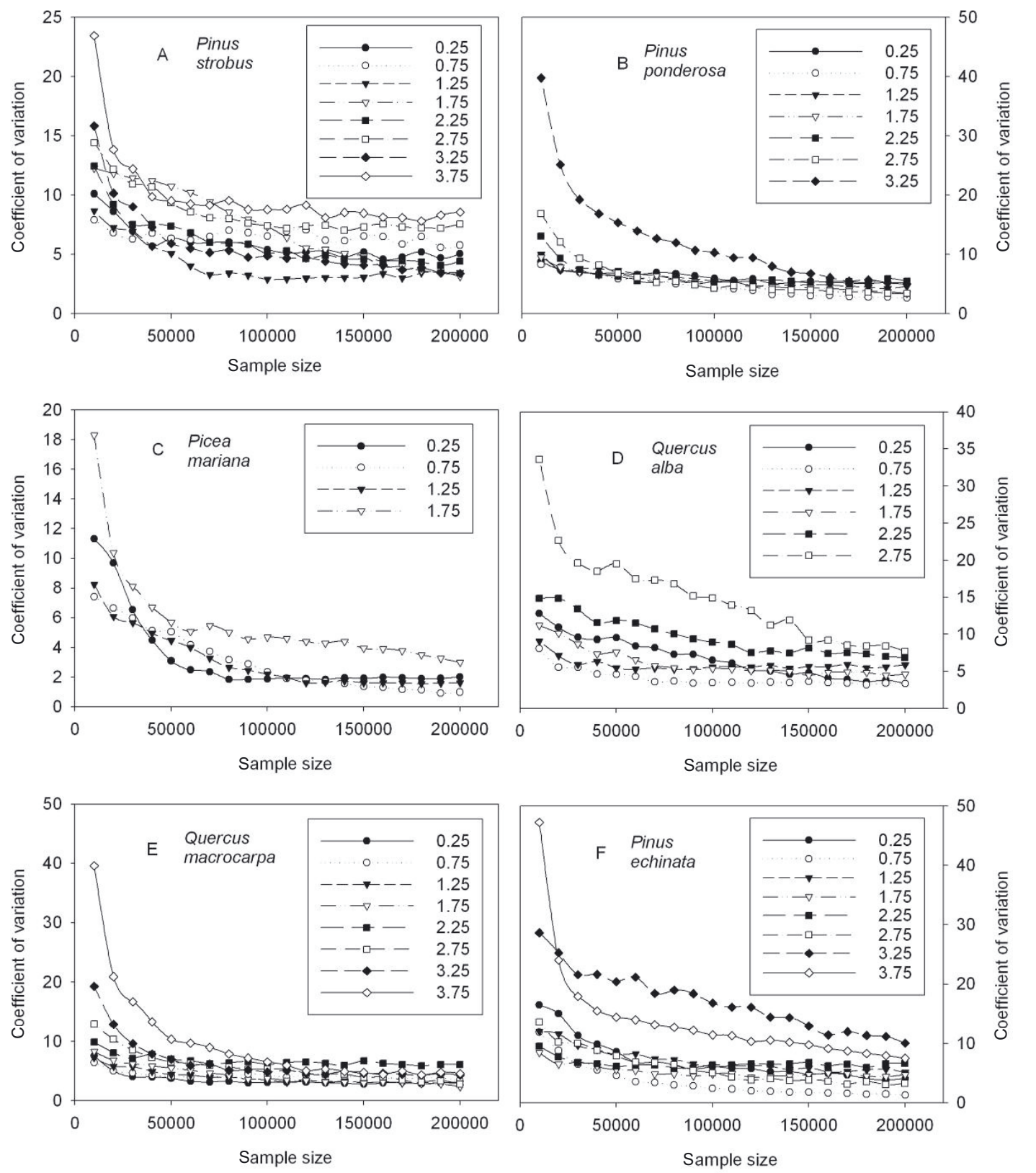

Figure 3. Coefficients of variation of maximum percent-growth change values in $0.5 \mathrm{~mm}$ prior-growth classes. Three hundred resamplings were performed at each sample size.

the American west where many dendrochronological studies were conducted for climate reconstructions (Grissino-Mayer and Fritts, 1997; Meko et al., 1993). Selecting trees on extreme sites where competition is low and the climate signal is strong could severely complicate the calculation of species' boundary lines. Relatively few if any trees would show maximum release responses, and bootstrapping may overestimate minimum sample sizes necessary to develop a boundary line. Yet even with these complications, the bootstrapping results are somewhat consistent in suggesting a minimum sample size of approximately 50000 data points for boundary line development given the type of data that are typically available.

\subsection{Effects of age and size}

An analysis of growth patterns in these eleven North American tree species indicates that prior growth does not fully compensate for the effects of age or size in most species. Among the species included in this study, effects of age and size are best mitigated in Tsuga canadensis. Percent growth change pulses fail to reach the boundary line (values $>90 \%$ of the boundary line) after the trees have reached approximately $350 \mathrm{~mm}$ in radius or 350 years in age (Tab. I and Figs. 4A, 4B). Considering that some individuals can reach ages of 550 years, an age of 350 includes approximately $64 \%$ of the species' 



Figure 4. Relationship between prior growth and percent growth change with respect to each $50 \mathrm{~mm}$ radius class (A, C, E) or 50 year age class $(\mathrm{B}, \mathrm{D}, \mathrm{F})$ in three tree species. 
maximum lifespan (Tab. I). Boundary line release criteria also appear to perform quite well at standardizing across various age and size classes for Picea mariana (Tab. I). Yet for majority of species, pulses in percent-growth change consistently fail to reach the prior growth boundary line at much younger ages and smaller sizes (Tab. I and Fig. 4).

In a preliminary analysis, understory tolerance appears to provide little predictive ability as to the age or size at which a species fails to attain percent growth change values that fall within $90 \%$ of the boundary line (Tab. I). In terms of absolute age $(F=2.47 ; p=0.15)$ or size $(F=2.11 ; p=0.18)$, or relative age $(F=1.86 ; p=0.22)$ or size $(F=14.36$; $p=0.002$ ) with respect to the largest or oldest individual observed, significant $(p<0.05)$ differences among the three tolerance classes only occur for relative size, according to an analysis of variances. Shade-tolerant species may reach very large sizes before they are no longer able to experience releases that approach the boundary line (Tab. I). However, this analysis is rather coarse, and when the data are investigated in more detail, the shade-intolerant species show a much more profound loss in ability to reach the boundary line, particularly with increasing age. For example, when data are plotted with respect to size and age classes, Pinus echinata and Quercus macrocarpa show much greater declines in release potential with increasing age than Tsuga canadensis (Fig. 4). The ability to attain the boundary line diminishes with increasing size and especially age, typical of the other shade-intolerant species and many species intermediate in shade tolerance.

The reduction in release response of fast-growing, shadeintolerant species and the retention of release response in the very shade-tolerant, slow growing Tsuga canadensis may reflect adaptations to the unique environments in which each group of species are most competitive. For example, the shadeintolerant species of this study tend to occupy droughty habitats characterized by historically high fire frequencies that would have reduced competition within and among species, especially among larger and older trees (Burns and Honkala, 1990). On the opposite extreme, Tsuga canadensis dominates closed, competitive stands and is adapted to capturing the frequent small gaps and occasional large gaps that typify an oldgrowth Tsuga canadensis forest (Abrams et al., 2000; Dahir and Lorimer, 1996). Unlike intolerant trees, large and old Tsuga canadensis maintain considerable foliage in the understory that can rapidly exploit any light allowed through the canopy by gap-forming events. Age and size may affect the ability of intolerant species to attain the boundary line and this should be thoroughly checked before applying boundary-line release criteria.

These age and size-related effects on maximum percentgrowth change may invalidate the species-wide boundary line for growth increments formed when trees become old and large. Yet before an appropriate set of methods can be developed to address this problem, the causes of these failures to reach the boundary line must first be understood. One possibility is that competitive influences are very low during those segments of a tree's lifespan in which it fails to reach the boundary line. Those species with the most pronounced age and size-related limitations in their ability to reach the bound- ary line may simply experience relatively little competition. Indeed, once mature, species with severe age and size-related reductions in release response such as Quercus stellata or Pinus ponderosa are often widely spaced such that competition is low and large portions of their crowns are exposed to direct light (Burns and Honkala, 1990). Even if a disturbance occurred in the stand, only a rather small percentage of foliage would be newly exposed and a minimal growth pulse would follow. In contrast, shade-tolerant species tend to occur in highly closed stands and maintain a large portion of foliage in the shade, even in larger, older trees. If a disturbance occurred under these conditions, a relatively large amount of foliage would be exposed, leading to large gains in total photosynthesis that could result in an acceleration of radial growth. Therefore, a growth pulse that reaches the boundary line may require a substantial reduction in competition, and those trees that stop showing maximal releases may have attained a position where competitive effects are consistently low. Until the mechanisms behind this inability to attain the boundary line are determined, release patterns cannot be properly interpreted for trees once they become older or larger, especially for shade-intolerant species.

Given these uncertainties as to why these larger or older trees fail to reach the boundary line, modifications of release criteria to include these age and size classes are premature. For now, size and age limits may be necessary, as has been proposed in past release criteria (Lorimer and Frelich, 1989; Nowacki and Abrams, 1997). Yet modifications of the boundary line approach may be possible once the responses of older, larger trees are better understood. If indeed the boundaries of maximum percent-growth change are low for older, larger trees, then size or age-specific subsets of the boundary line could be constructed to scale maximum percent-growth change. Inclusion of growth increments from trees after they become old and large could increase sample size and allow for more complete release analyses in stands dominated by older and large trees. Or once trees become old and large, they simply may not be very useful for reconstructing forest disturbances.

\subsection{Potential site influences}

An additional consideration in developing and applying boundary lines is whether a single boundary line is truly representative across many sites. The most thoroughly studied species to date is Tsuga canadensis in which trees from highelevation bog forests to steep talus to broad stream valleys all approach the boundary line if they have experienced sufficient disturbance (Black and Abrams, 2003; 2004). However, notable exceptions include sites near the northern boundaries of the species' range, which show unique relationships between prior growth and percent growth change (Black and Abrams, 2004). Overall, though, the tendency of most sites to follow a single boundary line agrees with the results in this study. For example, the percentage of sites that approach the boundary line is comparable among the majority of species, generally ranging from thirty to forty percent (Tab. I). The only exceptions are the two Picea species, in which the percentage of 

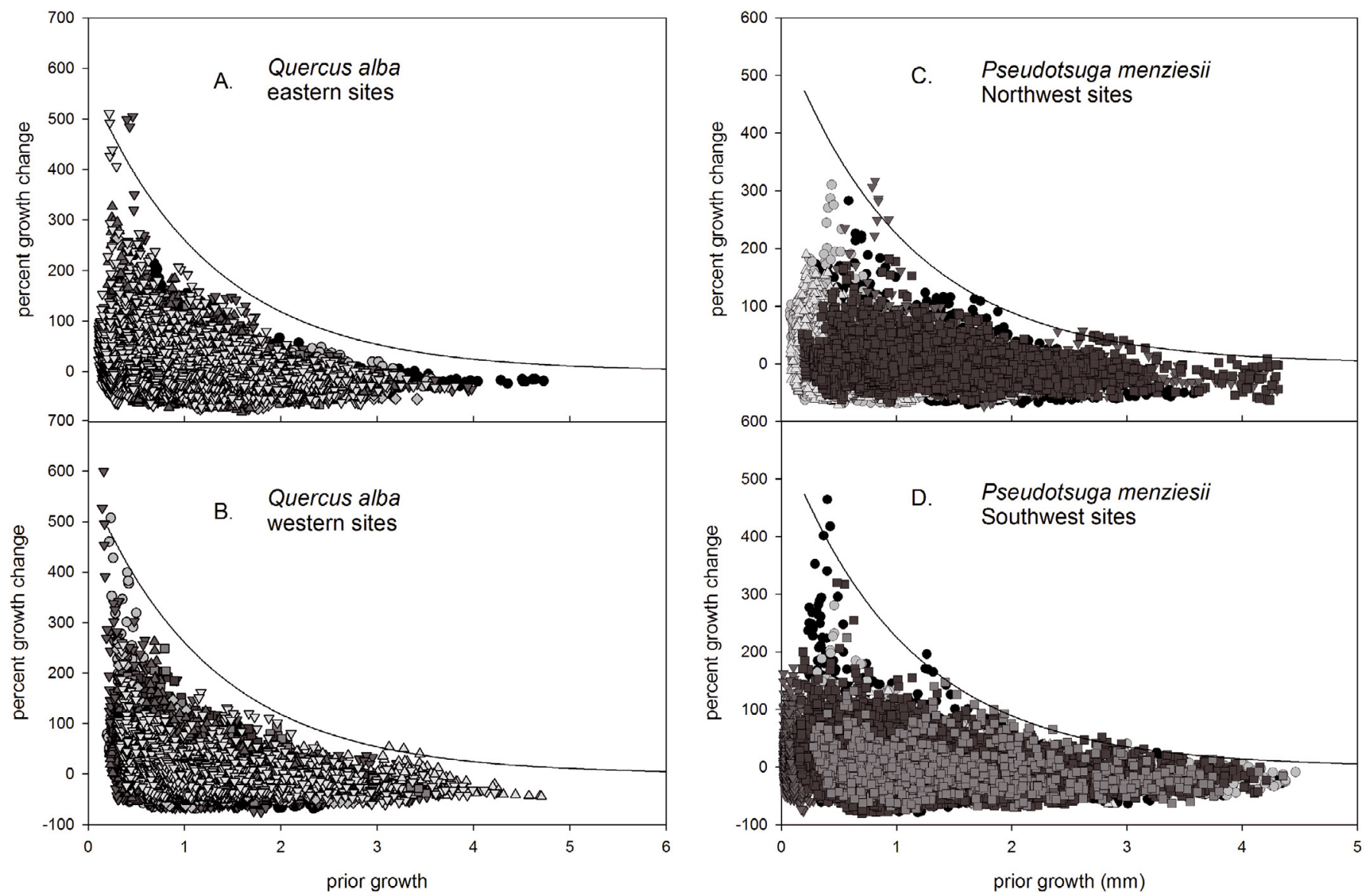

Figure 5. Relationship between prior growth and percent growth change for Pseudotsuga menziesii and Quercus alba sites. (A) Eastern portion of Quercus alba's range include Ohio, Pennsylvania, and Virginia. (B) Western Quercus alba sites include Minnesota, Iowa, and Missouri. The species-specific boundary line is shown for both species. (C) Northwest Pseudotsuga menziesii sites are located in the Cascade Mountains or Washington, Oregon, and Canada. (D) Southwestern Pseudotsuga menziesii sites are located in Arizona, New Mexico, and Mexico. Each symbol represents a different site.

sites that approach the boundary line is somewhat low at approximately twenty percent (Tab. I). Therefore, approximately one third of all data sets experience disturbance capable of eliciting a response that approaches the boundary line, or alternately, occupy sites that would require the development of unique boundary lines.

In a more detailed evaluation, Quercus alba on sites from the eastern portion of its range (Pennsylvania, New Jersey, Ohio, and Virginia) approach the boundary line (Fig. 5A) as do those on sites from the western portion of its range (Missouri, Iowa, and Minnesota) (Fig. 5B). Also, Pseudotsuga menziesii on sites from the Cascade Mountains of the Pacific Northwest (Oregon, Washington, and Canada) approach the boundary line (Fig. 5C) as do sites from the mountains of Arizona, New Mexico, and Mexico (Fig. 5D). The fact that trees located across broad portions of a species' range show similar level of release does not resolve potential influences of site conditions. Larger data sets that include more extreme sites and detailed records of site conditions will be necessary to better address the issue. Yet the existing data set provides evidence that a single boundary line appears could potentially be applied to the majority of locations in each species' range.

\subsection{Comparisons with running mean criteria}

An evaluation of Quercus prinus response to thinning treatments shows that scaling percent growth-change values to prior growth better reflects crown release than percent growthchange values alone (Fig. 6). In this study, maximum percent growth change pulses occurred within five years of the thinning treatment, as expected considering the three-year lag identified by Rentch et al. (2003) for this same data set. A simple linear regression of percent-growth change and crown release yields and $R^{2}$ value of 0.27 , which nearly doubles to an $R^{2}$ of 0.55 when the same values are scaled to the Quercus prinus boundary line (Fig. 6). As has been shown for running mean release criteria, the relationship between percent growth change and degree of crown release is linear (Rentch et al., 



Figure 6. (A) Relationship between percent crown exposed and percent growth change (as calculated using the Nowacki and Abrams 1997 formula) for Quercus prinus trees following a 1982 thinning treatment. (B) Relationship between percent crown exposed and the same percent growth-change values after expressing them as a percentage of the value predicted by the Quercus prinus boundary line.

2003), which also appears to be the case for boundary-line release criteria (Fig. 6). At the time of treatment (1982) average age was 54 years ( \pm 2 years) while average diameter was 21 $\mathrm{cm}( \pm 3 \mathrm{~cm})$. These trees were young and small enough that age- or size-related declines in the ability to reach the Quercus prinus boundary lines did not affect their response to disturbance (Tab. I). Yet even with this rather limited data set, the results of this analysis support the underlying assumption that prior growth better predicts the percent-growth change pulse that a tree experiences following a crown release.

\section{CONCLUSIONS}

In a recent review, Rubino and McCarthy (2004) identify thirty novel release criteria techniques, and hundreds of papers in which they have been implemented. Since that time, additional criteria have been developed, including an approach that utilizes time-series analysis to identify pulses, steps, and other changes in tree-ring measurement time series that could represent disturbance events (Druckenbrod, 2005), a "divergence method," that differentiates fine-scale from regional-scale disturbances (Thompson et al., 2007), and an "absolute-increase method" in which growth subsequent to an event is subtracted from growth prior to an event, indirectly incorporating the effects of prior growth on release response to distinguish disturbance events (Fraver and White, 2005). These release criteria vary widely, and each was formulated to accommodate a specific set of objectives for the species involved (Black and Abrams, 2004; Rubino and McCarthy, 2004). For example, criteria may be designed to identify small gap openings or catastrophic disturbance events, while others may focus upon the responses of a single species or group of species (Black and Abrams, 2004; Rubino and McCarthy, 2004). Also, release criteria may attempt to identify a single event in the lifespan of a tree, such as canopy accession date, or multiple events over a tree's lifetime (Lorimer and Frelich, 1989; Nowacki and Abrams, 1997).

Boundary-line release criteria are an extension of the Nowacki and Abrams (1997) criteria and must be interpreted accordingly. As in the original Nowacki and Abrams (1997) criteria, boundary line releases should reflect the degree of crown exposure a tree experiences following a disturbance event, as indicated in Quercus prinus. Also, boundary line criteria can capture multiple disturbance events from a single tree as currently formulated, though more conservative release thresholds may allow for detection of single major events, such as a canopy accession date. Limitations of the technique must be considered, including the failure of trees to attain the boundary line as they become old and large, particularly in shade-intolerant species. Also, the large sample sizes required to develop boundary line criteria are a potential complication, but one that could be offset by utilizing the growing International Tree-Ring Data Bank. Most importantly, integrating prior growth into release criteria does appear to help standardize release events across various size and age classes within a species, particularly within the first half of the average species' lifespan. Clear prior growth and percent-growth change relationships exist for all species examined, allowing for the potential development of boundary line release criteria across a diverse array of taxa, and facilitating more direct comparisons of disturbance histories among sites and even among species.

Acknowledgements: The authors thank Gary Miller, who established the Chestnut Ridge thinning treatment in 1982 and generously allowed access to the site for this study. We also thank contributors to the International Tree-Ring Data Bank.

\section{REFERENCES}

Abrams M.D., van de Gevel S., Dodson R.C., and Copenheaver C.A., 2000. The dendroecology and climatic impacts for old-growth white pine and hemlock on the extreme slopes of the Berkshire Hills, Massachusetts, USA. Can. J. Bot. 78: 851-861. 
Abrams M.D., Copenheaver C.A., Black B.A., and van de Gevel S., 2001. Dendroecology and climatic impacts for a relict, old-growth, bog forest in the Ridge and Valley Province of central Pennsylvania, USA. Can. J. Bot. 79: 58-69.

Black B.A. and Abrams M.D., 2003. Use of boundary-line growth patterns as a basis for dendroecological release criteria. Ecol. Appl. 13: $1733-1749$.

Black B.A. and Abrams M.D., 2004. Development and application of boundary-line release criteria. Dendrochronologia 22: 31-42.

Burns R.M. and Honkala B.H., 1990. Silvics of North America, U.S. Dept. of Agriculture, Forest Service, Washington, D.C.

Cade B.S. and Noon B.R., 2003. A gentle introduction to quantile regression for ecologists. Front. Ecol. Environ. 1: 412-420.

Dahir S.E. and Lorimer C.G., 1996. Variation in canopy gap formation among developmental stages of northern hardwood stands. Can. J. For. Res. 26: 1875-1892.

Druckenbrod D.L., 2005. Dendroecological reconstructions of forest disturbance history using time-series analysis with intervention detection. Can. J. For. Res. 35: 868-876.

Forrester J.A., Leopold D.J., and Art H.W., 2007. Disturbance history and mortality patterns in a rare Atlantic barrier island maritime holly forest. Nat. Area. J. 27: 169-182.

Fraver S. and White A.S., 2005. Identifying growth releases in dendrochronological studies of forest disturbance. Can. J. For. Res. 35: 1648-1656.

Grissino-Mayer H.D. and Fritts H.C., 1997. The International Tree-Ring Data Bank: An enhanced global database serving the global scientific community. Holocene 7: 235-238.

Lafon C.W. and Speer J.H., 2002. Using dendrochronology to identify major ice storm events in oak forests of southwestern Virginia. Clim. Res. 20: 41-54.

Lorimer C.G. and Frelich L.E., 1989. A Methodology for Estimating Canopy Disturbance Frequency and Intensity in Dense Temperate Forests. Can. J. For. Res. 19: 651-663.

Meko D., Cook E.R., Stahle D.W., Stockton C.W., and Hughes M.K., 1993. Spatial patterns of tree-growth anomalies in the United-States and southeastern Canada. J. Climate 6: 1773-1786.

Nagel T.A., Levanic T., and Diaci J., 2007. A dendroecological reconstruction of disturbance in an old-growth Fagus-Abies forest in Slovenia. Ann. For. Sci. 64: 891-897.
Nowacki G.J. and Abrams M.D., 1997. Radial-growth averaging criteria for reconstructing disturbance histories from presettlement-origin oaks. Ecol. Monogr. 67: 225-249.

Rentch J.S., Desta F., and Miller G.W., 2002. Climate, canopy disturbance, and radial growth averaging in a second-growth mixed-oak forest in West Virginia, USA. Can. J. For. Res. 32: 915-927.

Rentch J.S., Fajvan M.A., and Hicks R.R., 2003. Oak establishment and canopy accession strategies in five old-growth stands in the central hardwood forest region. For. Ecol. Manage. 184: 285-297.

Rozas V., 2003. Regeneration patterns, dendroecology, and forest-use history in an old-growth beech-oak lowland forest in Northern Spain. For. Ecol. Manage. 182: 175-194.

Rubino D.L. and McCarthy B.C., 2004. Comparative analysis of dendroecological methods used to assess disturbance events. Dendrochronologia 21: 97-115.

Ruffner C.M. and Abrams M.D., 1998. Relating land-use history and climate to the dendroecology of a 326-year-old Quercus prinus talus slope forest. Can. J. For. Res. 28: 347-358.

Schuler T.M. and Fajvan M.A., 1999. Understory tree characteristics and disturbance history of a Central Appalachian forest prior to oldgrowth harvesting, USDA Forest Service, Washington, DC.

Shumway D.L., Abrams M.D., and Ruffner C.M., 2001. A 400-year history of fire and oak recruitment in an old-growth oak forest in western Maryland, USA. Can. J. For. Res. 31: 1437-1443.

Speer J.H., Swetnam T.W., Wickman B.E., and Youngblood A., 2001. Changes in pandora moth outbreak dynamics during the past 622 years. Ecology 82: 679-697.

Splechtna B.E., Gratzer G., and Black B.A., 2005. Disturbance history of a European old-growth mixed-species forest - A spatial dendroecological analysis. J. Veg. Sci. 16: 511-522.

Thompson R.D., Daniels L.D., and Lewis K.J., 2007. A new dendroecological method to differentiate growth responses to fine-scale disturbance from regional-scale environmental variation. Can. J. For. Res. 37: 1034-1043.

Webster C.R. and Jensen N.R., 2007. A shift in the gap dynamics of Betula alleghaniensis in response to single-tree selection. Can. J. For. Res. 37: 682-689.

Winter L.E., Brubaker L.B., Franklin J.F., Miller E.A., and DeWitt D.Q., 2002. Canopy disturbances over the five-century lifetime of an oldgrowth Douglas-fir stand in the Pacific Northwest. Can. J. For. Res. 32: $1057-1070$. 


\section{Online Material}




\section{APPENDIX}

Tree-ring data sources used in the development of prior-growth boundary lines in this study as well as Black and Abrams, 2003 and 2004. Data sets may be accessed through the NOAA International Tree-Ring Databank at [http://www.ncdc.noaa.gov/paleo/treering.html].

\begin{tabular}{lll}
\hline Tsuga canadensis & & \\
Site & Source & Contributor \\
\hline Adirondack Mountain Reserve & ITRDB & Cook, E.R. \\
Alan Seeger & ITRDB & Cook, E.R. \\
Alger County & ITRDB & Cook, E.R. \\
Bear Meadows & Abrams et al. 2000 & Abrams, M.D. \\
Dingman's Falls State Park & ITRDB & Cook, E.R. \\
Hemlock Cove - Sunset Field & ITRDB & Cook, E.R. \\
Hemlocks Natural Area & ITRDB & Cook, E.R. \\
Ice Glen & Abrams et al. 2001 & Abrams, M.D. \\
Kelsey Tract & ITRDB & Cook, E.R. \\
Matawaumkeag & ITRDB & Cook, E.R. \\
Mohawk Trail & ITRDB & Cook, E.R. \\
Mount Rogers & ITRDB & Cook, E.R. \\
Pack Forest & ITRDB & Cook, E.R. \\
Pot Lake - Northwest Lake & ITRDB & Cook, E.R. \\
Presque Isle River & ITRDB & Cook, E.R. \\
Ramseys Draft & ITRDB & Puckett, L.J., Phipps, R.L. \\
Reviere du Moulin & ITRDB & Cook, E.R. \\
Rickett's Glen State Park & ITRDB & Cook, E.R. \\
Salt Point & ITRDB & Cook, E.R. \\
Salt Springs State Park & ITRDB & Cook, E.R. \\
Savage Gulf & ITRDB & Cook, E.R. \\
Shenandoah National Park & ITRDB & Cook, E.R. \\
Sweetroot Natural Area & ITRDB & Cook, E.R. \\
Tionesta Natural Area & ITRDB & Cook, E.R. \\
\hline
\end{tabular}




\begin{tabular}{|c|c|c|}
\hline \multicolumn{3}{|l|}{ Picea glauca } \\
\hline Site & Source & Contributor \\
\hline Armstrong & ITRDB & F. H. Schweingruber \\
\hline Arrigetch & ITRDB & B. Buckley, R. D. D’Arrigo, G. C. Jacoby \\
\hline Austin Lake & ITRDB & F. H. Schweingruber \\
\hline Border Beacon & ITRDB & H. E. Wright, H. C. Fritts \\
\hline Bruno Lake & ITRDB & F. H. Schweingruber \\
\hline Capotigaman & ITRDB & F. H. Schweingruber \\
\hline Castle Peninsula & ITRDB & B. Buckley, R. D. D'Arrigo, G. C. Jacoby \\
\hline Claire River & ITRDB & H. C. Fritts, T. Knowles, C. W. Stockton \\
\hline Don Jeck River Bridge & ITRDB & F. H. Schweingruber \\
\hline Eureka Summit & ITRDB & F. H. Schweingruber \\
\hline Ft. Simpson McKenzie River & ITRDB & F. H. Schweingruber \\
\hline High Stone Lake & ITRDB & F. H. Schweingruber \\
\hline MacKenzie Mountains & ITRDB & B. Buckley, R. D. D’Arrigo, G. C. Jacoby \\
\hline Northway Junction & ITRDB & F. H. Schweingruber \\
\hline Glenn Highway & ITRDB & F. H. Schweingruber \\
\hline Pine Pass & ITRDB & F. H. Schweingruber \\
\hline Sheenjek River and Flats & ITRDB & B. Buckley, R. D. D’Arrigo, G. C. Jacoby \\
\hline Slana Bei Tok & ITRDB & F. H. Schweingruber \\
\hline Smithers Ski Area & ITRDB & F. H. Schweingruber \\
\hline Twisted Tree Heartrot HIll & ITRDB & B. Buckley, R. D. D’Arrigo, G. C. Jacoby \\
\hline Wakuach Lake & ITRDB & F. H. Schweingruber \\
\hline Webequie & ITRDB & F. H. Schweingruber \\
\hline Willow Island & ITRDB & F. H. Schweingruber \\
\hline Wolverine Plateau & ITRDB & M. L. Parker, W. E. S. Henock \\
\hline Athabasca River & ITRDB & H. C. Fritts, T. Knowles, C. W. Stockton \\
\hline Buffalo Lake & ITRDB & F. H. Schweingruber \\
\hline Canyon Creek & ITRDB & A. H. Lloyd \\
\hline Mount Billy Mitchell & ITRDB & F. H. Schweingruber \\
\hline Fort Providence & ITRDB & F. H. Schweingruber \\
\hline Fox River Bank & ITRDB & A. H. Lloyd \\
\hline
\end{tabular}




\begin{tabular}{lll}
\hline Picea mariana & & \\
Site & Source & Contributor \\
\hline Bonif historisc & ITRDB & F. H. Schweingruber \\
Capotigaman & ITRDB & F. H. Schweingruber \\
Charlie Lake & ITRDB & F. H. Schweingruber \\
Chitina (peat Bog) & ITRDB & K. Kaiser \\
Christmas Crekk & ITRDB & K. Kaiser \\
Eastmain River feucht & ITRDB & F. H. Schweingruber \\
Eastmain River trocken & ITRDB & F. H. Schweingruber \\
Esker & ITRDB & F. H. Schweingruber \\
Fishing Creek & ITRDB & F. H. Schweingruber \\
Gunisao Lake & ITRDB & F. H. Schweingruber \\
Kathleen Lake & ITRDB & F. H. Schweingruber \\
Lac Chevrillon & ITRDB & F. H. Schweingruber \\
Lac Natuak (trocken) & ITRDB & F. H. Schweingruber \\
Lac Natuak & ITRDB & F. H. Schweingruber \\
Lac Peribonca & ITRDB & F. H. Schweingruber \\
Lac Romanel & ITRDB & F. H. Schweingruber \\
Lac Romanel (Feucht) & ITRDB & F. H. Schweingruber \\
Mac Kinely & ITRDB & F. H. Schweingruber \\
No Name Lake & ITRDB & F. H. Schweingruber \\
Wakuach Lake & ITRDB & F. H. Schweingruber \\
Willow Lake & ITRDB & F. H. Schweingruber \\
Yasinski Lake (Feucht) & ITRDB & F. H. Schweingruber \\
Sakiw Creek Burwash Landing & ITRDB & F. H. Schweingruber \\
No Name Lake (Trocken) & ITRDB & F. H. Schweingruber \\
Willow Lake Insel & ITRDB & F. H. Schweingruber \\
Yasinski Lake (Trocken) & ITRDB & F. H. Schweingruber \\
\hline & &
\end{tabular}

\begin{tabular}{lll}
\hline Pinus echinata & & \\
Site & Source & Contributor \\
\hline Athens & ITRDB & H. D. Grissino-Mayer \\
Clemson Forest & ITRDB & M. K. Cleaveland \\
Clifty Canyon & ITRDB & D. W. Stahle \\
Drury House & ITRDB & D. W. Stahle \\
Ellen Cockran Hollow & ITRDB & D. W. Stahle \\
Horton House & ITRDB & D. W. Stahle \\
Jacob Wolf House & ITRDB & D. H. Jurney, D. Wolfman, D. W. Stahle. \\
Lake Winona & ITRDB & D. W. Stahle \\
Lead Mine Hampton Hills & ITRDB & A. C. Barefoot \\
Levi Wilcoxon & ITRDB & G. G. Hawks, D. W. Stahle \\
Roaring Branch & ITRDB & S. Schoenholtz, G.C. Jacoby, E.R. Cook, \\
& & D.W. Stahle \\
Hot Springs & ITRDB & S. Schoenholtz, G.C. Jacoby, E.R. Cook, \\
& & D.W. Stahle \\
Lower Rock Creek & ITRDB & D. N. Duvick \\
Lynn Hollow and Look Rock Trail & ITRDB & W. Blozan, M. D. Therrell, D. W. Stahle \\
Magazine Mountain 2 & ITRDB & E. T. Estes \\
McCurtain County & ITRDB & S. Schoenholtz, G.C. Jacoby, E.R. Cook, \\
& & D.W. Stahle \\
New Hill Beaver Tree Farm & ITRDB & A. C. Barefoot \\
Ozark & ITRDB & E. T. Estes \\
Pine Hills 4 & ITRDB & E. T. Estes \\
Piney Creek & ITRDB & E. T. Estes \\
Shannon County & ITRDB & R. P. Guyette \\
Sylamore & ITRDB & E. T. Estes \\
\hline
\end{tabular}




\begin{tabular}{|c|c|c|c|}
\hline \multicolumn{4}{|l|}{ Pinus ponderosa } \\
\hline Abouselman Spring & ITRDB & \multicolumn{2}{|c|}{ A. M. Lynch, A. C. Caprio, T. W. Swetnam } \\
\hline Alcova Resevoir Site A & ITRDB & \multicolumn{2}{|c|}{ T. P. Harlan, M. A. Stokes } \\
\hline Antelope Lake & ITRDB & \multicolumn{2}{|c|}{ R. K. Adams, R. L Holmes } \\
\hline Baca & ITRDB & \multicolumn{2}{|c|}{ A. M. Lynch, A. C. Caprio, T. W. Swetnam } \\
\hline Beaver Creek & ITRDB & \multicolumn{2}{|c|}{ D. A. Graybill } \\
\hline Big Elk Meadows & ITRDB & \multicolumn{2}{|c|}{ B. J. Raimo, A. M. Lynch, T. W. Swetnam } \\
\hline Black Forest East & ITRDB & \multicolumn{2}{|c|}{ P. M. Brown, C. A. Woodhouse } \\
\hline Defiance East (Fort Defiance) & ITRDB & M. A. Stokes & \\
\hline Buckhorn Mountain & ITRDB & C. H. Sieg, D & Meko \\
\hline Cabresto Canyon & ITRDB & A. M. Lynch, & A. C. Caprio, T. W. Swetnam \\
\hline Capulin Volcano & ITRDB & P. M. Brown, & C. A. Woodhouse \\
\hline Cat Mesa & ITRDB & A. M. Lynch, & A. C. Caprio, T. W. Swetnam \\
\hline Crater Lake & ITRDB & T. W. Swetna & , J. H. Speer \\
\hline Cross Canyon Arizona & ITRDB & W. J. Robins & , J. S. Dean \\
\hline Crystal Cave Sequoia National Park & ITRDB & L. J. Graumli & h, J. C. King \\
\hline Dalton Resevoir & ITRDB & R. K. Adams & R. L Holmes \\
\hline Devil's Gulch & ITRDB & B. J. Raimo, & M. Lynch, T. W. Swetnam \\
\hline Drumhill Ridge & ITRDB & C. H. Baisan, & T. W. Swetnam, B. E. Wickman \\
\hline Elephant Rock & ITRDB & A. M. Lynch, & A. C. Caprio, T. W. Swetnam \\
\hline El Valle & ITRDB & W. J. Robins & 1, J. S. Dean \\
\hline Emigrant Springs & ITRDB & C. H. Baisan, & T. W. Swetnam, B. E. Wickman \\
\hline Fish Lake & ITRDB & C. H. Baisan, & T. W. Swetnam, B. E. Wickman \\
\hline Gila Cliff Dwellings & ITRDB & D. A. Graybi & \\
\hline Granite Mountain (NW of Prescott) & ITRDB & T. P. Harlan, & 1. A. Stokes \\
\hline Pinus strobus & & & \\
\hline Site & Soul & & Contributor \\
\hline Backbone State Park & ITR & & Landers, R., Duvick, D.N. \\
\hline Basin Pond & ITR & & Swain, Henselman, A.M. \\
\hline Bluffton & ITR & & Landers, R., Duvick, D.N. \\
\hline Devils' Lake State Park & ITR & & Cook, E.R. \\
\hline Dividing Lake & ITR & & Guyette, R.P. \\
\hline Ige Glen & Abr & ns et al. 2001 & Abrams, M.D. \\
\hline Longfellow Trail & ITR & & Cook, E.R. \\
\hline Presque Isle River & ITR & & Cook, E.R. \\
\hline Soper Brook West Branch & ITR & & Cook, E.R. \\
\hline St-Marguerite & ITR & & Krause, C., Gionest, F. \\
\hline Swan Lake Algonquin Park & ITR & & Guyette, R.P., Cole, B. \\
\hline Westward Lake & ITR & & Guyette, R.P., Cole, B. \\
\hline White Pine Hollow Forest Preserve & ITR & & Landers, R., Duvick, D.N. \\
\hline Wilmington Notch Roaring Brook & ITR & & Cook, E.R. \\
\hline Winch Pond Adirondack Mountains & ITR & & Cook, E.R. \\
\hline
\end{tabular}




\begin{tabular}{|c|c|c|}
\hline \multicolumn{3}{|l|}{ Pseudotsuga menziesii } \\
\hline Alpine San Francisco River Watershed & ITRDB & C. W. Stockton \\
\hline Baldy Peak & ITRDB & F. H. Schweingruber, K. Briffa \\
\hline Bear Lake & ITRDB & F. H. Schweingruber \\
\hline Big Boulder Creek & ITRDB & L. B. Brubaker \\
\hline Black Canyon of the Gunnison River & ITRDB & T. P. Harlan, M. A. Stokes \\
\hline Bobcat Canyon & ITRDB & $\begin{array}{l}\text { M. K. Cleaveland, D. O. Bowden, } \\
\text { W. J. Robinson, J. S. Dean }\end{array}$ \\
\hline Butte & ITRDB & M. L. Parker, C. W. Ferguson \\
\hline Cerro Baraja & ITRDB & B. T. Burns, M. K. Cleaveland, D. W. Stahle \\
\hline Chicago Creek & ITRDB & T. P. Harlan, M. A. Stokes \\
\hline Clarks Fork of the Yellowstone & ITRDB & L. J. Gaumlich, L. Waggoner \\
\hline Creel International Airport & ITRDB & B. T. Burns, M. K. Cleaveland, D. W. Stahle \\
\hline Deer Creek Pass & ITRDB & G. Segura, L. B. Brubaker, C. J. Earle \\
\hline Dolores & ITRDB & T. P. Harlan \\
\hline Eagle Point & ITRDB & L. B. Brubaker \\
\hline El Salto West Sierra Madre & ITRDB & R. L Holmes, T. P. Harlan, M. A. Stokes \\
\hline Elbow Campground Jackson & ITRDB & M. L. Parker, C. W. Ferguson \\
\hline Fly Peak Chiricahua Mountains & ITRDB & F. H. Schweingruber, K. Briffa \\
\hline Gallinas Mountains & ITRDB & C. W. Stockton \\
\hline Helena & ITRDB & E. B. Ferguson, C. W. Ferguson \\
\hline Kamloops & ITRDB & H. C. Fritts \\
\hline Laramie Site A Woods Creek & ITRDB & T. P. Harlan, M. A. Stokes \\
\hline Lily Lake & ITRDB & P. M. Brown, C. A. Woodhouse \\
\hline Los Alamos, New Mexico & ITRDB & D. O’Brien \\
\hline Quercus alba & & \\
\hline Site & Source & Contributor \\
\hline Backbone State Park & ITRDB & $\begin{array}{ll}\text { B } & \text { D. N. Duvick }\end{array}$ \\
\hline Buffalo Beats North Ridgetop Fores & ITRDB & B D. B. Houston, J. R. McClenahen \\
\hline Cass Lake B & ITRDB & B L. J. Graumlich \\
\hline Current River Natural Area & ITRDB & B D. N. Duvick \\
\hline Dolliver Memorial State Park & ITRDB & D. N. Duvick \\
\hline Dysart Woods & ITRDB & B. C. McCarthy, D. L. Rubino \\
\hline Fox Ridge State Park & ITRDB & B D. N. Duvick \\
\hline Greasy Creek & ITRDB & D. N. Duvick \\
\hline Hutchenson Forest & ITRDB & E. R. Cook \\
\hline Lacey-Keosauqua State Park & ITRDB & D. N. Duvick \\
\hline Lilley Cornett Tract & ITRDB & E. R. Cook \\
\hline Lower Rock Creek & ITRDB & D. N. Duvick \\
\hline Mammoth Cave & ITRDB & E. T. Estes \\
\hline Mountain Lake Virginia & ITRDB & E. R. Cook \\
\hline Patty's Oaks Blue Ridge Parkway & ITRDB & E. R. Cook \\
\hline Pulaski Woods & ITRDB & E. R. Cook \\
\hline Fire Tower Road Creek Forest & ITRDB & E. R. Cook \\
\hline Lincoln's New Salem State Park & ITRDB & D. N. Duvick \\
\hline Pinnacle Point/ Hawksville Gap & ITRDB & E. R. Cook \\
\hline Roaring River & ITRDB & D. W. Stahle \\
\hline Sipsey Wilderness & ITRDB & E. R. Cook \\
\hline Wegener Woods & ITRDB & D. W. Stahle \\
\hline Yellow River State Forest & ITRDB & D. N. Duvick \\
\hline Joyce Kilmer Wilderness & ITRDB & E. R. Cook \\
\hline
\end{tabular}




\begin{tabular}{|c|c|c|}
\hline $\begin{array}{l}\text { Quercus macrocarpa } \\
\text { Site }\end{array}$ & Source & Contributor \\
\hline Assiniboine River Alluvial Logs & ITRDB & S. St. George \\
\hline Blair & ITRDB & C. H. Sieg, D. Meko \\
\hline Bruce Park & ITRDB & S. St. George \\
\hline Cedar Cliff Farm & ITRDB & D. N. Duvick, R. Landers \\
\hline Cross Ranch Sanger Unit & ITRDB & C. H. Sieg, D. Meko \\
\hline Crystal Cave & ITRDB & C. H. Sieg, D. Meko \\
\hline Custer State Park & ITRDB & C. H. Sieg, D. Meko \\
\hline Fort Dufferin & ITRDB & S. St. George \\
\hline Frawley & ITRDB & C. H. Sieg, D. Meko \\
\hline Frawley Dairy Farm & ITRDB & C. H. Sieg, D. Meko \\
\hline Grace Coolidge & ITRDB & C. H. Sieg, D. Meko \\
\hline Marais River & ITRDB & S. St. George \\
\hline Mud River & ITRDB & C.W. Stockton \\
\hline Orland Hutterite Colony & ITRDB & C. H. Sieg, D. Meko \\
\hline Preparation Canyon State Park & ITRDB & D. N. Duvick, R. Landers \\
\hline Red River Alluvial Logs & ITRDB & S. St. George \\
\hline Rockerville & ITRDB & C. H. Sieg, D. Meko \\
\hline Shay & ITRDB & S. St. George \\
\hline St. Jean Baptiste & ITRDB & S. St. George \\
\hline Stone State Park & ITRDB & C. H. Sieg, D. Meko \\
\hline St. Norbert & ITRDB & S. St. George \\
\hline St. Vital Park & ITRDB & S. St. George \\
\hline Ste. Agathe & ITRDB & S. St. George \\
\hline Hankins Group & ITRDB & C. H. Sieg, D. Meko \\
\hline Horseshoe Lake & ITRDB & S. St. George \\
\hline Hyland Park & ITRDB & S. St. George \\
\hline Icelandic State Park Pembina Hills & ITRDB & C. H. Sieg, D. Meko \\
\hline Kildonan Park & ITRDB & S. St. George \\
\hline Killdeer-Dvirnak & ITRDB & C. H. Sieg, D. Meko \\
\hline LaBarriere Park & ITRDB & S. St. George \\
\hline Lake Herman State Park & ITRDB & C. H. Sieg, D. Meko \\
\hline Masonic Island/ Bear Island & ITRDB & C. H. Sieg, D. Meko \\
\hline Munsen Park & ITRDB & S. St. George \\
\hline Parker Farm & ITRDB & S. St. George \\
\hline Remus Farm & ITRDB & S. St. George \\
\hline Sandwich & ITRDB & D. N. Duvick \\
\hline Manitoba Historical Timbers & ITRDB & S. St. George \\
\hline Thompson & ITRDB & C. H. Sieg, D. Meko \\
\hline Winnipeg & ITRDB & S. St. George \\
\hline \multicolumn{3}{|l|}{ Quercus prinus } \\
\hline Site & Source & Contributor \\
\hline Blue Ridge Parkway & ITRDB & Cook, E.R. \\
\hline Fernow Experimental Forest & ITRDB & Adams, H.S. et al. \\
\hline Greenbriar & ITRDB & Young, J., Blozan, W. \\
\hline Lynn Hollow & ITRDB & Stahle, D.W., Therrell, M.D. \\
\hline Mohonk Lake & ITRDB & Cook, E.R. \\
\hline Otter Creek Natural Area & ITRDB & Cook, E.R. \\
\hline Stebbin's Gulch Holden Arb. & ITRDB & Cook, E.R. \\
\hline Watch Dog Massenhutten Mountain & ITRDB & Cook, E.R. \\
\hline
\end{tabular}




\begin{tabular}{lll}
\hline $\begin{array}{l}\text { Quercus stellata } \\
\text { Site }\end{array}$ & Source & Contributor \\
\hline Bluestem Lake & ITRDB & D. W. Stahle \\
Buffalo Park Boundary & ITRDB & M. D. Therrell, D. W. Stahle \\
Capote Knob & ITRDB & D. W. Stahle \\
Coleto Creek & ITRDB & D. W. Stahle \\
Ecleto Creek & ITRDB & M. K. Cleaveland, A. M. Dunne, \\
& & M. D. Therrell, D. W. Stahle \\
Fall River & ITRDB & D. W. Stahle \\
Greasy Creek & ITRDB & D. N. Duvick \\
Hahatonka & ITRDB & D. W. Stahle \\
Jack's Fork & ITRDB & D. N. Duvick \\
Lake Arbuckle & ITRDB & D. W. Stahle \\
Leon River & ITRDB & D. W. Stahle \\
Little Maries River & ITRDB & D. W. Stahle \\
Lower Rock Creek & ITRDB & D. N. Duvick \\
Mason Mountain & ITRDB & D. W. Stahle \\
McCurtain County & ITRDB & D. W. Stahle \\
Mill Mountain & ITRDB & M. K. Cleaveland, M. D. Therrell, \\
& & R. P. Guyette, D. W. Stahle \\
Neosho River & ITRDB & D. W. Stahle \\
Oakwood & ITRDB & D. W. Stahle \\
Pomme de Terre & ITRDB & D. W. Stahle \\
Quanah Mountain & ITRDB & D. W. Stahle \\
Roaring River & ITRDB & D. W. Stahle \\
Toronto Lake & ITRDB & D. W. Stahle \\
\hline
\end{tabular}

